DOI:

\title{
1500 V DC Beslemeli Raylı Sistemlerde Solar Hücre Sisteminin Modellenmesi ve Fizibilitesi
}

\author{
Ender GÜZELLER ${ }^{1}$, Mehmet Taciddin AKÇAY ${ }^{2}$, \\ Bahattin Bulut ALBAYRAK ${ }^{3}$
}

\author{
${ }^{1}$ Metro İstanbul, Raylı Sistem Projeler Departmanı, İstanbul, Türkiye. \\ ORCID ID:orcid.org/0000-0002-9546-3117 \\ 2̇̇stanbul Büyükşehir Belediyesi, Raylı Sistem Daire Başkanlığı, İstanbul, Türkiye. \\ ORCID ID:orcid.org/0000-0002-1050-4566 \\ ${ }^{3}$ Maestro Mühendislik, İstanbul, Türkiye. \\ ORCID ID:orcid.org/0000-0002-6070-9914
}

Geliş Tarihi: 26.11 .2019

*Sorumlu Yazar e mail: taciddin.akcay@ibb.gov.tr Kabul Tarihi: 04.02.2020

Atıf/Citation: Güzeller, E., Akçay, M.T. ve Albayrak B.B. "1500 V DC Beslemeli Raylı Sistemlerde Solar Hücre Sisteminin Modellenmesi ve Fizibilitesi”, Haliç Üniversitesi Fen Bilimleri Dergisi 2020, 3/1: 19-34.

Araştırma Makalesi/ Research Article

\section{Özet:}

Dünyada enerji tüketimi sürekli olarak arttığı için ihtiyaç olan enerjinin bir kısmı yeni enerji kaynakları ile karşılanmaktadır. Bu enerji kaynaklarının seçiminde doğaya katkısı ve kaynak verimi açısından yenilenebilir enerji kaynakları tercih edilmektedir. Güneş enerjisi yenilenebilir enerji kaynakları içerisinde önemli bir paya sahiptir. Elektrikli demiryollarında güç ihtiyacı yüksek mertebelere ulaştığı için tüketilen enerjinin optimize edilerek kullanılması gerekmektedir. Yenilenebilir enerji kaynaklarının demiryollarında kullanılması enerji tüketiminin kontrol edilmesinde büyük öneme sahiptir. Bu çalışmada 1500 V DC beslemeli bir raylı sistem hattında solar hücre sisteminin modellenmesi ve fizibilitesi araştırılmıştır. Kullanılan alana ait fizibilite yapılarak tasarımın optimal şartlara sahip olması hedeflenmiştir. Çalışma için bir raylı sistem hattına ait veriler kullanılarak hesaplamalar yapılmış ve sistem analiz edilmiştir. Elde edilen sonuçlar karşılaştırmalı olarak verilerek sistemin performansı ve doğrulanabilirliği ortaya konulmuştur.

Anahtar Kelimeler: Besleme, Fizibilite, Model, Raylı sistem, Solar hücre 


\title{
Modeling and Feasibility of Solar Cell System in $1500 \mathrm{~V}$ DC Feed Rail Systems
}

\begin{abstract}
:
Since energy consumption increases continuously in the world, some of the energy that is needed is provided by new energy sources. Renewable energy sources are preferred in terms of their contribution to nature and resource efficiency in the selection of these energy sources. Solar energy has an important part in renewable energy sources. Since the power requirement of electric railways reaches high levels, the energy consumed should be optimized and used. The use of renewable energy sources on railways is of great importance in controlling energy consumption. In this study, the modeling and feasibility of solar cell system in a rail system line with 1500 V DC supply was investigated. The feasibility of the area used is intended to have optimal conditions for the design. For the study, calculations were made using the data of a rail system line and the system was analyzed. The results obtained were given comparatively and the performance and the applicability of the system were demonstrated.
\end{abstract}

Keywords: Feed, Feasibility, Model, Rail system, Solar cell.

\section{Giriş}

Raylı sistem yatırımları yüksek yolcu taşıma kapasitesi ve yolcu konfor seçeneklerinden dolayı hız kesmeden devam etmektedir. Raylı sistemler kütüphanesi bünyesinde birçok alt branşı barındıran karmaşık sistemleri içermektedir [1]. Raylı sistemlerle ilgili yatırımlar arttıkça sistemin işletme giderleriyle ilgili optimizasyon konuları önem kazanmaktadır. Raylı sistemlerde sistem performansını etkileyen çeşitli işletme parametreleri bulunmaktadır [2]. Sistemin en kritik işletme harcamalarından birini elektrik tüketimi oluşturmaktadır. Raylı sistemlerde yüksek güç tüketen ekipmanlar ve raylı taşımacılığı sağlayan güçlü araçlar kullanıldığı için enerji ihtiyacı yüksek olmaktadır. Raylı Sistemlerde araç işletmesi için gerekli olan gerilim EN 50163 ile belirlenmiştir [3]. DC beslemeli raylı sistemlerde sağladığı avantajlardan dolayı çoğunlukla $1500 \mathrm{~V}$ DC besleme gerilimi tercih edilmektedir 
[4]. Raylı sistemlerde yüksek elektrik tüketimi yeni enerji kaynaklarının sisteme entegre edilmesi gerekliliğini ortaya çıkarmıştır. Bundan ötürü yenilenebilir enerji kaynaklarının kullanımı bu sistemler için büyük önem arz etmektedir. Yenilenebilir enerji kaynakları olarak güneş enerjisi, rüzgar enerjisi ve tünel 1sı enerjisi yaygın olarak kullanılmaktadir.

Güneş enerjisi, kurulum kolaylığ 1 ve diğer faktörler bakımından çoğunlukla tercih nedeni olarak sayılmaktadır. Türkiye'de güneş enerjisi kapasitesi en yüksek olan bölge Güney Doğu Anadolu Bölgesi olup, bunu Akdeniz Bölgesi takip etmektedir [5]. Türkiye'de yenilenebilir enerji kaynakları arasında en yüksek potansiyele sahip olan sistem, güneş enerjisi sistemidir [6]. Güneş enerjisi doğal bir enerji türü olarak fotovoltaik yöntemle (PV) enerji üreterek doğaya kirletici madde yaymayarak az su tüketen yenilenebilir enerji çeşididir [7]. Güneş enerjisi tükenmeyen ve temiz üretim gerçekleştiren bir enerji kaynağıdır [8]. Türkiye'nin güneşten yararlanma oranı İspanya dışındaki tüm Avrupa ülkelerinden önde yer almaktadır [9]. Dünya genelinde enerji talebi \% 79 ile fosil yakıtlardan karşılanmaktadır. Fosil yakıtların mevcut rezervi her geçen gün azalmaktadır. Petrol, kömür ve doğalgaz gibi dönüşümsüz enerji kaynakları bu kategoriye girmekte$\operatorname{dir}$ [10-12]. Fotovoltaik enerji sistemlerinde hareketli parçaların olmaması işletme ve bakım maliyetlerini oldukça düşürmektedir [13]. EİE (Elektrik İleri Etüd İdaresi Genel Müdürlügü) bazlı yapılan bir araştırmaya göre, ortalama yıllık toplam güneşlenme süresi 2640 saat, ortalama toplam 1şınım şiddeti $1311 \mathrm{kWh} / \mathrm{m}^{2}$-yıl olduğu ortaya konulmuştur [14]. Güneş enerji sisteminin en büyük dezavantajı güneşin sürekli bir kaynak görevi görmeden kesintili olarak kullanılabilmesidir [15]. Raylı sistem altyapıları şehiriçi ulaşımda özellikle yeraltı güzergahlarında bulunduğu için güneş enerjisi sisteminin kullanımı limitli olmaktadır. Metro sistemlerinde tünel yapısı yerin altında bulunduğundan güneş gören bölge olarak istasyon yapısının bulunduğu kısım elverişli olmaktadır. Şekil 1 ile güneş enerjisiyle elektrik enerjisinin elde edilişi gösterilmektedir. 


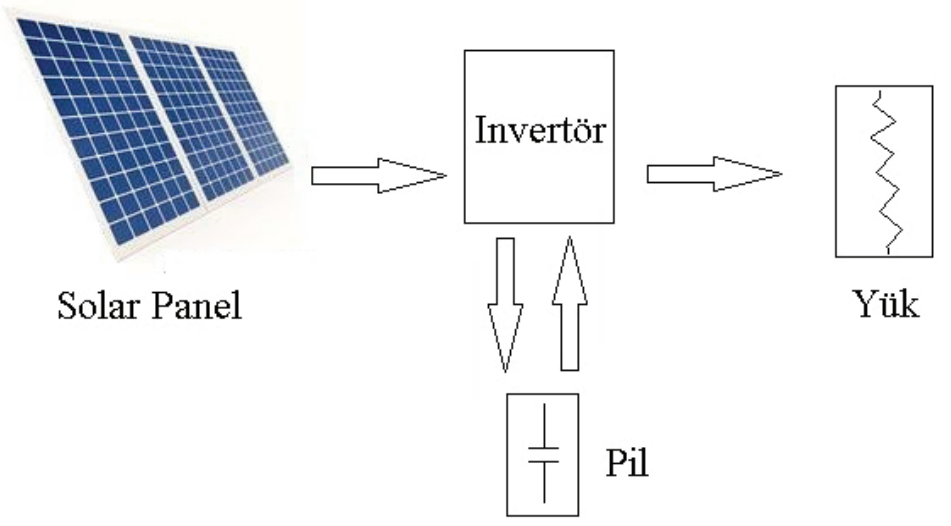

Şekil 1. Güneş Enerjisiyle Elektriğin Elde Ediliş̧i

Güneş enerjisi sistemi solar gövde paneli, invertör, pil ve sisteme bağlanan yüklerden oluşmaktadır. İnvertör DC-AC gerilim dönüşümü için kullanılmaktadır. Pil üretilen DC gerilimin depolanması için gerekmektedir. Bir PV hücresi yaklaşık $1 \mathrm{~W}$ güç üretmekte olup daha yüksek güçlerin elde edilmesi için birden fazla PV hücresi seri ve paralel olarak bağlanarak modül yapısı oluşturulmaktadır. Bu yöntemle paneller, ve paneller vasitasıyla diziler oluşturulmaktadır [16]. Bir PV hücresi gelen solar enerjinin sadece \% 4 ile \% 20 kadarını elektrik enerjisine dönüştürebilmekte olup kalan enerji ısıya dönüştürülmektedir [17]. Gelişen teknolojiyle birlikte otomasyon sistemlerine entegre olan solar panel ekipmanının güneş 1şığının açısına bağlı olarak hareket etmesiyle sistemin verimi arttırılmaktadır. Bu şekilde güneş 1şığ1nın gelme açısının değişmesine bağlı olarak yaşanan kayıpların azaltılması hedeflenmektedir. Aynı şekilde merkezi SCADA bilgisayarı ile ilgili sisteme ait veriler kayıt altına alınarak elde edilen enerji ve tüketim değerleri grafik üzerinden gösterilebilmektedir. Bu veriler 1ş1ğında sisteme ait performans raporları oluşturulmaktadır. Yine bu veriler kullanılarak sistem için gerekli olan işletme ve bakım maliyetleri hesaplanabilmektedir. 


\section{Materyal ve Metot}

$\mathrm{Bu}$ çalışma kapsamında bir raylı sistem hattına ait bir istasyon yapısinda solar panel sistemine ait benzetim Matlab/Simulink ortamında yapılmıştır. Benzetim için hatta ait verilerden faydalanılmıştır. Benzetim için güneş alan cephenin değiştirilmesine bağlı olarak sistem ayrı ayrı analiz edilerek sonuçlar kayıt altına alınmıştır.

\subsection{Fotovoltaik enerji}

Güneş enerjisi sisteminde fotovoltaik enerji, solar paneller vasıtasıyla elde edilmekte olup eş değer devre şeması şekil 2 ile gösterilmektedir. $I_{L}$ üretilen akım1, $I_{d}$ diyot akım1, $R_{s}$ ve $R_{s h}$ seri ve paralel direnci ifade etmektedir. V devre gerilimini, I ise devre akımını sembolize etmektedir.

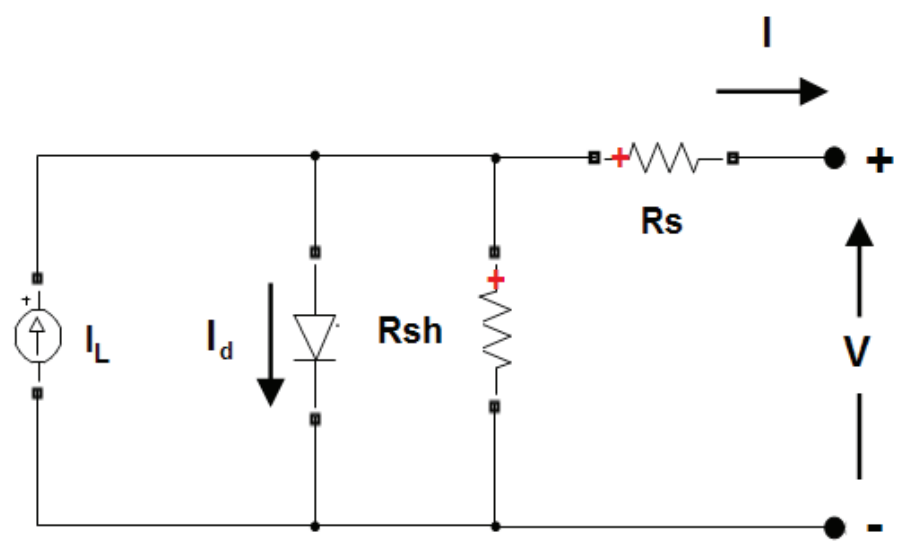

Şekil 2. PV Panel Devre Şeması [Matlab]

(1) ve (2) eşitlikleri ile diyot gerilim ve akım karakteristikleri elde edilmektedir. Denklemlerle elde edilen karakteristik durumlara ait eğriler şekil 3 ile gösterilmektedir. 


$$
\begin{aligned}
& I_{d}=I_{0}\left[\exp \left(\frac{V_{d}}{V_{T}}\right)-1\right] \\
& V_{T}=\frac{k T}{q} \times n I \times N_{\text {hücre }}
\end{aligned}
$$

(1) ifadesinde $I_{d}$ diyot akımını, $I_{0}$ diyot doygunluk akımını, $V_{d}$ diyot gerilimini, $\mathrm{V}_{\mathrm{T}} \mathrm{T}$ sıcaklığında gerçekleşen gerilimi ifade etmektedir. (2) eşitliğinde ise T sıcaklı̆̆ı, $\mathrm{k}$ boltzman katsayısını, nI diyodun idealite faktörünü, $\mathrm{N}_{\text {hücre }}$ modüldeki seri bağlı hücre sayısını ifade etmektedir.

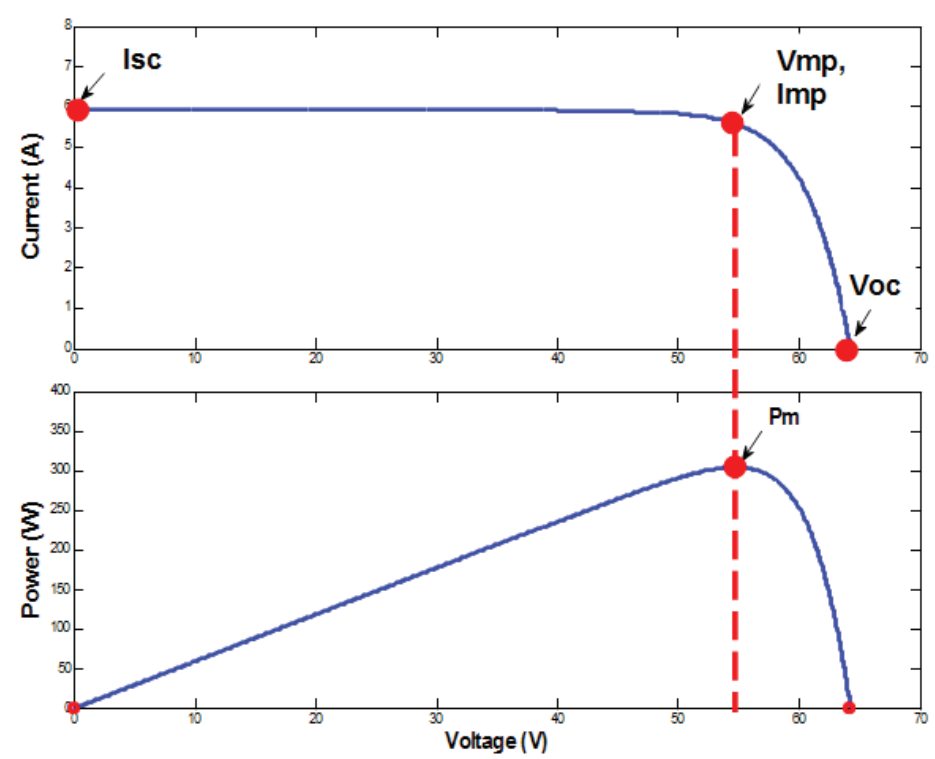

Şekil 3. PV Panel V-I ve P-V Karakteristikleri [Matlab]

Eğride yer alan $\mathrm{I}_{\mathrm{sc}}$ kısa devre akımını, $\mathrm{V}_{\mathrm{oc}}$ açık devre gerilimini, $\mathrm{P}_{\mathrm{m}}$ maksimum güç noktasını, $\mathrm{V}_{\mathrm{mp}}$ ve $\mathrm{I}_{\mathrm{mp}}$ maksimum güç noktasındaki gerilim ve akım değerlerini ifade etmektedir. (3) ve (4) eşitlikleri ile $\mathrm{V}_{\mathrm{OC}}$ ve $I_{\text {SC }}$ değerlerine ait sıcaklık katsayıları hesaplanmaktadır. Beta_V $V_{O C}$ ve alpha_I $I_{S C}$ ilgili katsayıları temsil etmektedir. 


$$
\begin{aligned}
& V_{O C_{T}}=V_{O C}\left(1+\text { beta_ }_{-} V_{O C}(T-25)\right) \\
& I_{S C_{T}}=I_{S C}\left(1+\text { alpha_ } I_{S C}(T-25)\right)
\end{aligned}
$$

(5) denklemi ile maksimum güç ifadesi elde edilmektedir.

$$
P_{\max }=V_{m p} \times I_{m p}
$$

\subsection{Benzetim alanı ve kapasite}

Benzetim için Alibeyköy Cep Otogarı metro istasyonunun viyadük yapısı üzerinde tasarım yapılmıştır. Yapılan yerleşimde kullanılan birim panel ölçüleri ve viyadük yapısı şekil 4 ile verilmektedir. Bu yapı güneş enerjisi sisteminin veriminden dolayı tercih edilmiştir.
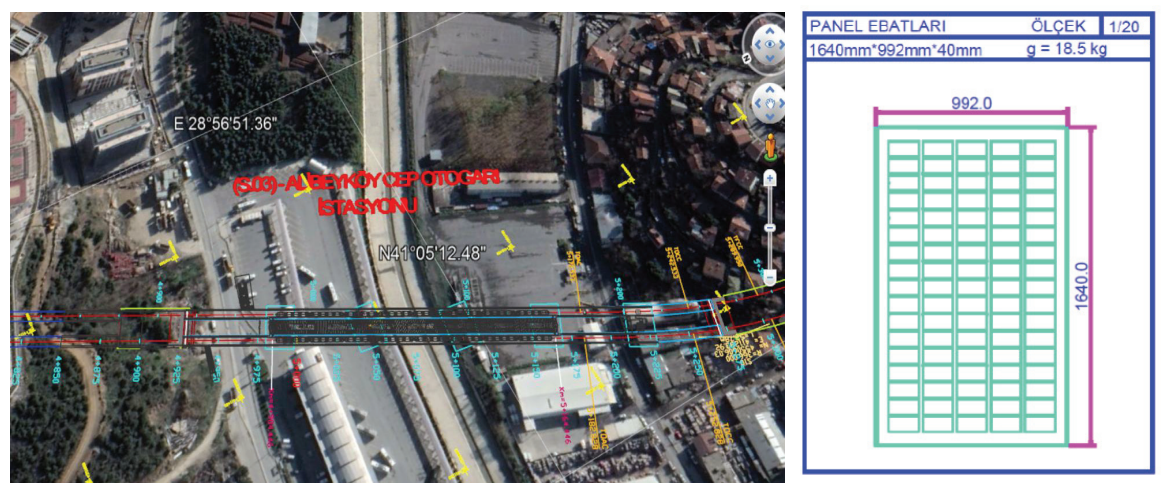

Şekil 4. Alibeyköy Cep Otogarı Viyadük Yapısı ve Panel Ölçüleri [18]

İstasyonun yerleşimi coğrafi olarak 41.0 derece kuzey enlemi ile 28.6 derece doğu boylamında bulunmaktadır. İstasyonun üst cephesinde 7 adet aynı özelliklere sahip kanopi yapısı bulunmaktadır. Bir kanopide panel yerleşimi yapılırken 7 derece açı ile kuzeydoğuya, 38 derece açıyla güneybatıya ve 4 derece açı ile kuzeydoğuya bakacak şekilde tasarım yapılmıştır. Yerleşim kanopi malzemesine ait düzleme paralel olacak şekilde yapılmıştır. Şekil 5 ile kanopi yapısı ve benzetim alanı gösterilmektedir. 


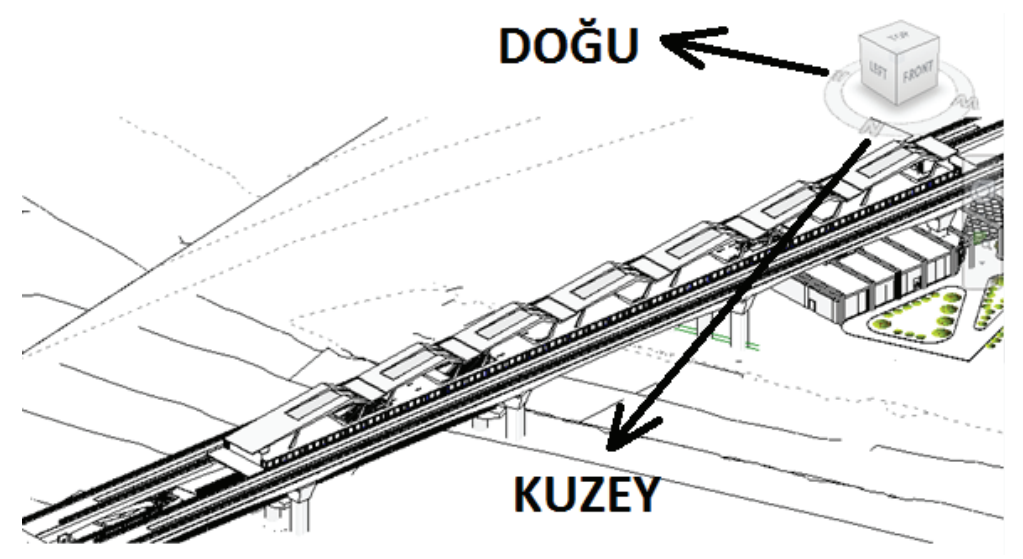

Şekil 5. Benzetim Alanı ve Kanopi Yapıs1 [18]

Benzetim yapılırken 3 farklı açıya ait tasarım koşulları ele alınarak sonuçlar elde edilmiştir. Elde edilen sonuçlar karşılaştırmalı olarak verilmiştir. Her grup için benzetim yapılmasının ardından üretilen güç hesaplanarak elde edilen ekonomik yararlar ayrıca araştırılmıştır.

\section{3 Üretilen gücün ifadesi}

Üç ayrı tasarım için üretilen güce ait sonuçlar tablo 1 ile gösterilmektedir. Bu tablo ile bir kanopi için elde edilen sonuçlara yer verilmiştir. Birim kanopi için üretilen değerler kullanılan toplam kanopi adediyle çarpılarak üretilen toplam güç ifadesi bulunmaktadır. Aşağıda bir kanopiye ait teknik özellikler verilmektedir.

Tablo 1. Bir Kanopiye ait Gücün İfadesi

\begin{tabular}{cccc}
\hline Yerleşim Açıs1 & 7 Derece & 38 Derece & 4 Derece \\
\hline Panel Sayısı (Adet) & 51 & 12 & 18 \\
Panel Gücü (Watt) & 275 & 275 & 275 \\
Kurulu Güç (Watt) & 14025 & 3300 & 4950 \\
Üretilen Elektrik (kWh/y1) & 15228 & 4146 & 5631 \\
$\begin{array}{c}\text { 1 Wp panel gücü ile 1 yılda üretile- } \\
\text { bilecek elektrik enerjisi (kWh/Wp) }\end{array}$ & 1.09 & 1.26 & 1.14 \\
\hline
\end{tabular}


Açılara bağlı olarak güneş enerjisinden elde edilen güç miktarı değişkenlik göstermektedir. Farklı derecelerde yapılan yerleşimler panel yerleşim sayısını değiştirmektedir. Verim açısından değerlendirme yapılırken birim üretim değerleri ele alınmaktadır.

\subsection{Sistemin kayıp analizi diyagramı}

Solar sistem işletme halinde iken sistem bileşenlerine bağlı olarak bazı kayıplar oluşmaktadır. Bu duruma ait diyagram şekil 6 ile gösterilmektedir. Solar sistem kurulurken sisteme ait verim koşulları ayrıca ele alınarak gerekli tasarım yapılmaktadır.

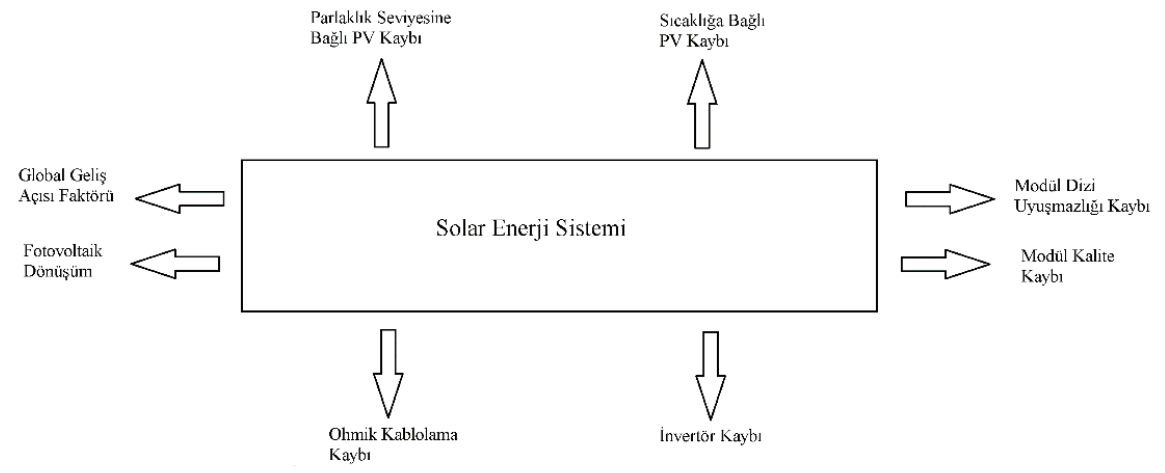

Şekil 6. Solar Sisteme Ait Kayıp Diyagramı

Solar sistem işletmeye alındığında parlaklık seviyesine bağlı PV (Fotovoltaik) kayıpları, sıcaklığa bağlı PV kaybı, ohmik kablolama kayıpları, invertör kayıpları, global geliş açısı faktörüne bağlı kayıplar, fotovoltaik dönüşüm kayıpları, modül dizi uyuşmazlığı kayıpları ve modül kalite kayıpları ortaya çıkmaktadır. 


\section{Bulgular ve Tartışma}

$\mathrm{Bu}$ çalışmada $1500 \mathrm{~V} \mathrm{DC}$ beslemeli bir raylı sistem hattında solar hücre sisteminin modellenmesi ve benzetimi yapılmıştır. Benzetim için Seyrantepe-Alibeyköy metro projesine ait verilerden yararlanılmıştır. Benzetim için 7 derece açı ile kuzeydoğuya, 38 derece açıyla güneybatıya ve 4 derece açı ile kuzeydoğuya bakacak şekilde olan yerleşim alanlarına göre sistem ayrı ayrı çalıştırılarak sonuçlar kayıt altına alınmıştır.

\subsection{Derece açı ile kuzeydoğuya bakan yerleşim alanlarına ait benzetim sonuçları}

Benzetim için 7 derece açı ile kuzeydoğu cepheye ait yerleşim durumu baz alınarak sistem çalıştırılmıştır. Bu durumda üretilen güce ait dağılım şekil 7 ile gösterilmektedir. Hesaplamalar için bir yıllık dönem baz alınarak sonuçlar kayıt altına alınmıştır. Benzetim için güneş enerjisi sisteminin bütününe ait oluşan kayıplar ayrıca dikkate alınarak değerler verilmiştir.
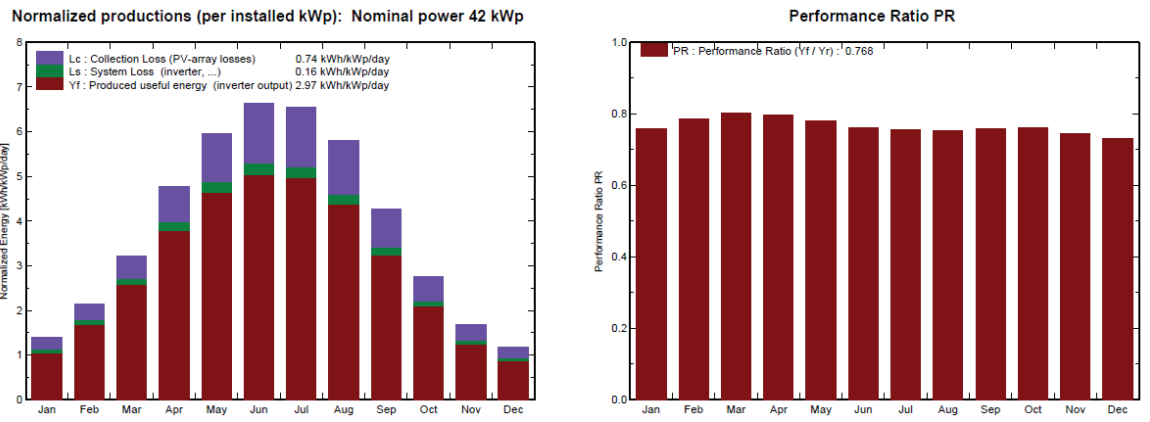

Şekil 7. 7 Derece Açı ile Kuzeydoğu Cepheye Ait Yerleşim Durumuna İlişkin Sonuçlar

$\mathrm{Bu}$ durumda güneş enerjisinden üretilen elektrik enerjisi 45.7 MWh/y1l olarak hesaplanmaktadır. Performans değeri ise \% 76 
olarak öngörülmüştür. Üretilen gücün dağılımı yılın aylarına göre yapılarak sonuçlar verilmiştir. Yıllık enerji dağılımına göre en fazla enerji haziran ayında elde edilirken en az enerjinin elde edildiği ay aralık olmaktadır. Mor renk ile Fotovoltaik modüle ait kayıplar ifade edilirken, yeşil renk ile invertör ve diğer ekipmanlardan oluşan sistem kayıpları gösterilmiştir. Bordo renk ile üretilen net enerji belirtilmiştir.

\subsection{Derece açı ile güneybatıya bakan yerleşim alanlarına ait benzetim sonuçları}

38 derece açı ile güneybatıya bakan yerleşim durumu esas alınarak sistem oluşturulmuştur. Bu durumda elde edilen enerjinin bir yıllık dönem için aylara göre dağılımı şekil 8 ile verilmektedir.
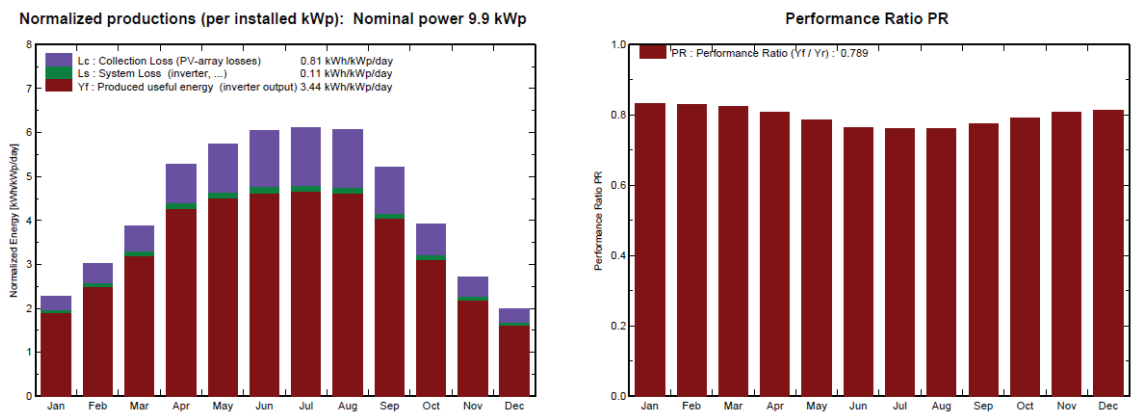

Şekil 8. 38 Derece Açı ile Güneybatıya Bakan Yerleşim Durumuna Ait Sonuçlar

Güneş enerjisinden üretilen elektrik enerjisi bu durumda 12.44 $\mathrm{MWh} / \mathrm{y} 1 \mathrm{l}$ olarak hesaplanmaktadır. Performans değeri ise \% 78.9 olarak belirlenmiştir. Yıllık enerji dağılımına göre en fazla enerji temmuz ayında elde edilirken en az enerji aralık ayında üretilmektedir. Fotovoltaik modüle ait kayıplar, invertör ve diğer ekipmanlardan oluşan sistem kayıpları ve üretilen net enerji ayrı ayrı renklerle belirtilmiştir. 


\subsection{Derece açı ile kuzeydoğuya bakan yerleşim alanlarına ait benzetim sonuçları}

Benzetim, 4 derece açı ile kuzeydoğuya bakan yerleşim durumuna uygulanmıştır. Bu durumda güneş enerjisiyle üretilen enerji şekil 9 ile ifade edilmektedir.
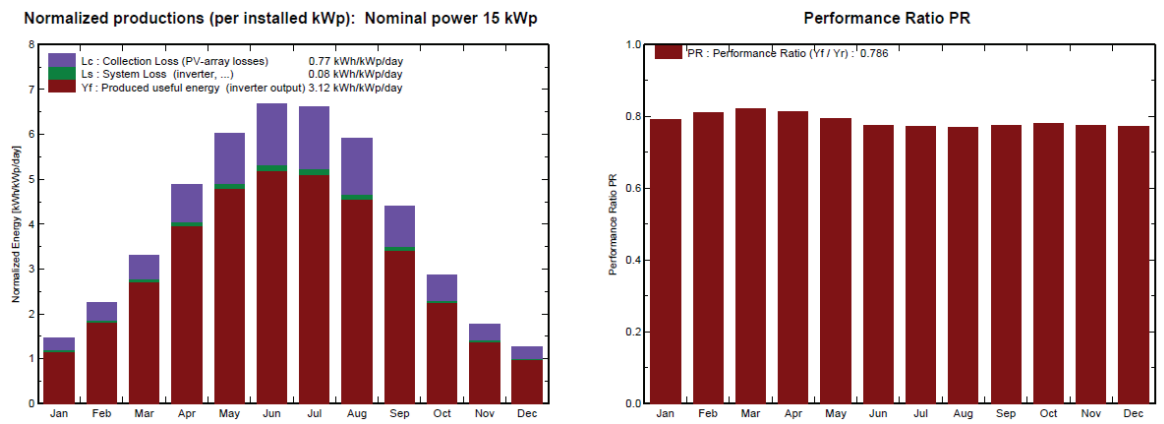

Şekil 9. 4 Derece Açı ile Kuzeydoğuya Bakan Yerleşim Durumuna Ait Sonuçlar

$\mathrm{Bu}$ koşullarda güneş enerjisinden üretilen elektrik enerjisi 16.89 MWh/yıl olarak hesaplanmaktadir. Performans ise hesaplamalar sonucunda \% 78.6 olarak ortaya çıkmaktadır. Yıllık enerji dağılımına bakıldığında en fazla enerji haziran ayında elde edilirken en az enerji aralık ayında üretilmektedir. Sistemde oluşan kayıpları ve üretilen net enerji ayrı ayrı renklerle ifade edilmiştir.

\subsection{Sonuçlara ait finansal değerlendirme}

Güneş enerjisi sistemiyle ilgili tasarlanan mimariye uygun olarak araştırılan finansal değerlendirme tablo 2 ile verilmektedir. Bu şekilde sistemin yatırım için fizibilitesi araştırılarak elverişli durumlar dikkate alınmaktadır. Üretilen enerji ile sistemin maliyeti kıyaslanarak sistem ile ilgili mali durum ortaya konulmuştur. 
Tablo 2. Solar Sisteme ait Finansal Değerlendirme

\begin{tabular}{cc}
\hline Hesaplanan Değişken & Değer \\
\hline Birim Panel Yatırım Maliyeti (EUR/Wp) & 0.65 \\
Toplam Panel Kurulu Gücü (W) & 155925 \\
Toplam Yatırım Maliyeti (EUR) & 101351.25 \\
Döviz Kuru (TL/EUR) & 6.3 \\
Toplam Yatırım Maliyeti (TL) & 638512.87 \\
Elektrik Birim Fiyatı (TL) & 0.54 \\
Y1llık Elektrik Üretimi (kWh/yıl) & 175035 \\
Yıllık Elektrik Üretiminin Mali Karşılığı (TL) & 94518.9 \\
Amortisman Süresi (yıl) & 6.75 \\
\hline
\end{tabular}

Solar sistem tarafindan üretilen enerji ile elde edilen toplam gelir değeri yatırım maliyetiyle kıyaslandığında sistemin tamamı kendini 6-7 yıl arasında amortisman etmektedir. Birim yatırım maliyetleri ile kullanılan ekipmanlar hesaplandığında bu değere ulaşılmaktadır. $\mathrm{Bu}$ veriler ile sisteme ait mali durum ve sistemin fizibilitesi ortaya konulmaktadir.

\subsection{Sonuçlara ait özet durum}

Solar sistem tasarımına ait üç ayrı cepheyle ilgili yapılan çalışmalar incelendiğinde tablo 3 ile verilen durum ortaya çıkmaktadır. Sistem mimarilerine göre üretilen elektrik enerjisi, sistemlerin performans değerleri, elektrik enerjisinin maksimum ve minimum üretildiği aylar bu tabloda belirtilmiştir. 
Tablo 3. Yerleşim Cephelerine Bağlı Durumların Özeti

\begin{tabular}{cccc}
\hline Yerleşim Açısı & 7 Derece & 38 Derece & 4 Derece \\
\hline Üretilen Elektrik Enerjisi (MWh/yıl) & 45.7 & 12.44 & 16.89 \\
Performans Değeri & $\% 76.8$ & $\% 78.9$ & $\% 78.6$ \\
En Yüksek Üretim Ayı & Haziran & Temmuz & Haziran \\
En Düşük Üretim Ayı & Aralık & Aralık & Aralık \\
\hline
\end{tabular}

Tasarımlar arasında performans değeri en yüksek olan mimari \% 78.9 performans değeri ile 38 derece açıyla güneybatı cepheye bakan tasarımdır. Üretilen gücün miktarı bakımından karşılaştırma yapıldığında ise $45.7 \mathrm{MWh} / \mathrm{y}$ ıl değeri ile 7 derece açı ile kuzeydoğuya bakan mimariye ait tasarımın en yüksek kapasiteye sahip olduğu belirlenmiştir.

\section{Sonuçlar}

$\mathrm{Bu}$ çalışma ile DC beslemeli raylı sistemlerde solar enerji sisteminin modellenmesi araştırılarak sonuçlar üzerinden analiz yapılmıştır. Çalışma kapsamında bir raylı sistem hattına ait viyadük istasyon yapısına sahip bir hatta ait verilerden yararlanılmıştır. Yerleşim kanopi malzemesine ait düzleme paralel olacak şekilde yapılarak tasarım cephesi 7 derece açı ile kuzeydoğuya, 38 derece açıyla güneybatıya ve 4 derece açı ile kuzeydoğuya bakacak şekilde ayrı ayrı durumlar araştırılmıştır. Yapılan tasarımlar için finansal değerlendirme tablosu hazırlanarak durumun fizibilitesi çıkarılmıştır. Solar sistem tasarımına ait üç ayrı cepheyle ilgili yapılan çalışmalar incelenerek ortaya çıkan durum özet şekilde verilmiştir. Tasarımlara ait üretilen elektrik enerjisi, elde edilen performans değerleri ve üretimin maksimum ile minimum olduğu aylara ait bilgiler verilmiştir. 7 derece açı ile kuzeydoğu cepheye bakan tasarımda üretilen güç $45.7 \mathrm{MWh} / \mathrm{y}$ ıl olurken 38 derece açı ile güneybatı cepheye bakan tasarımda üretilen güç $12.44 \mathrm{MWh} /$ yıl olmaktadır. 4 Derece açı ile kuzeydoğuya bakan çalışmada ise elde edilen 
güç 16.89 MWh/yıl değerini almaktadır. 7 derece ve 4 derece kuzeydoğuya bakan tasarımlarda maksimum ile minimum elektrik üretim ayı sırasıyla haziran ile aralık olurken 38 derece güneybatıya bakan sistemde bu aylar temmuz ile aralık olmaktadır. Tasarımlara ait performans değerleri araştırıldığında güneybatıya bakan tasarımın kuzeydoğuya bakan tasarımlara göre daha yüksek performans değerine sahip olduğu ortaya çıkmaktadır. Ortaya konulan tasarımın kendini finanse etme süresi ise 6.75 yıl olarak hesaplanmıştır. Bu sürenin bitmesinin ardından elde edilen durum bakım ve işletme giderleri çıkarıldığında sisteme kazanç olarak eklenecektir. Raylı sistemlerde yüksek enerji tüketiminden dolayı elektrik işletme giderleri çok yüksek mertebelere çıkabildiği için solar enerji gibi yenilenebilir enerji kaynaklarının kullanımı yaygınlaştırılarak bu ve benzeri çalışmaların desteklenmesi gerekmektedir.

\section{Kaynaklar}

[1] Akçay, M., T., Kocaarslan, İ. Simulation of Multi-Vehicle Signaling System with Matlab / Simulink and Design of Train Timetable, Journal of Science and Engineering, 6, (2019), 799-807.

[2] Akçay, M., T., Kocaarslan, İ. Determination Of Distance Between DC Traction Power Centers İn A 1500 V DC Subway Line With Artificial İntelligence Methods, Turkish Journal of Electrical Engineering \& Computer Sciences, 27, (2019), 289-303.

[3] Akçay, M., T., Kocaarslan, İ. Solving Power Quality Problem of 750 V DC Railway Substation With DSTATCOM Using SVPWM, (IJERAD), 11 (2), (2017), 620-626.

[4] Akçay, M., T., Kocaarslan, İ. Analysis of Catenary Short Circuit Case in a 1500 V DC Fed Railway Line With a Dynamic Model Algorithm, Journal of Natural and Applied Sciences, 2, (2019), 143-160

[5] Atmaca, M. , Yusufoğlu, G., Kurtuluş A. Güneş Enerjili Sulamanın Tarım Sektöründe Uygulaması. Bitlis Eren Üniversitesi Fen Bilimleri Dergisi, 3(2), (2015), 153-142.

[6] Taşkın, O. , Korucu, T. Determination of Solar Energy Potential in Kahramanmaras Province. KSÜ Doğa Bilimleri Dergisi, 17(4), (2015), 16-12. 
[7] Nedimoğlu, E., Gümüş, B. Şebekeye Bağlı Güneş Enerjisi Santrallerinin Harmoniklerine Etki Eden Parametrelerin Araştırılması. Dicle Üniversitesi Mühendislik Fakültesi Mühendislik Dergisi, 10(3), (2019), 931-919.

[8] Yalçın, C., Yüce, M. Burdur'da Güneş Enerjisi Santrali (GES) Yatırımına Uygun Alanların CBS Yöntemiyle Tespiti. Geomatik. 5(1), (2019), 50-40.

[9] Kırbaş, İ. , Çifci, A., İşyarlar, B. Burdur İli Güneşlenme Oranı ve Güneş Enerjisi Potansiyeli. Mehmet Akif Ersoy Üniversitesi Fen Bilimleri Enstitüsü Dergisi, 4(2), (2013), 23-20.

[10] Haydaroğlu, C., Gümüş, B. Dicle Üniversitesi Güneş Enerjisi Santralinin PVsyst ile Simülasyonu ve Performans Parametrelerinin Değerlendirilmesi. Dicle Üniversitesi Mühendislik Fakültesi Mühendislik Dergisi, 7(3), (2016), 500491.

[11] Rüstemli, S., Rüstemli, S., Dinçer, F., Çelik, M., Cengiz, M. Fotovoltaik Paneller: Güneş Takip Sistemleri ve İklimlendirme Sistemleri. Bitlis Eren Üniversitesi Fen Bilimleri Dergisi, 2(2), (2013), 147-141.

[12] Sayın, S., Koç, İ. Güneş Enerjisinden Aktif Olarak Yararlanmada Kullanılan Fotovoltaik (PV) Sistemler Ve Yapılarda Kullanım Biçimleri. Selçuk Üniversitesi Mühendislik, Bilim Ve Teknoloji Dergisi, 26(3), (2011), 106-89.

[13] Çetin, E., Sazak, B. Fotovoltaik Enerji Dönüşüm Sistemlerinde Kullanılabilecek Bir Seri Rezonans İnvertör Devresinin İncelenmesi. Pamukkale Üniversitesi Mühendislik Bilimleri Dergisi, 10(3), (2004), 346-339.

[14] Koç, A., Aksal, M. Güneş Enerjisinin Taşıtlarda Kullanımı ve Kırıkkale Üniversitesi Güneş Enerjili Araç Projesi Örneği. International Journal of Engineering Research and Development, 4(2), (2012), 20-15.

[15] Çifci, A., Kırbaş, İ., İşyarlar, B. Güneş Pili Kullanılarak Burdur'da Bir Evin Ortalama Elektrik İhtiyacının Karşılanması. Mehmet Akif Ersoy Üniversitesi Fen Bilimleri Enstitüsü Dergisi, 5(1), (2014), 17-14.

[16] Bulut, K., Ü., Uçar, S . Konut Çatı Ve Cephelerinde Farklı Fotovoltaik Sistem Uygulamalarının Değerlendirilmesi. Trakya Üniversitesi Mühendislik Bilimleri Dergisi. 19(2), (2018), 76-65.

[17] Ali, H. Experımental Investıgatıon Of Monocrystallıne And Polycrystallıne Solar Modules At Different Inclination Angles. Journal of Thermal Engineering, 4(4), (2018), 2148-2137.

[18] İBB, Raylı Sistem Daire Başkanlığı, Teknik Tasarım Dokümanları, 2019 